\title{
Article \\ Evaluating Biosedimentation for Strength Improvement in Acidic Soil
}

\author{
Ahmed Hassan Saad ${ }^{1}{ }^{(D}$, Haslinda Nahazanan ${ }^{1, *}$, Zainuddin Bin Md Yusoff ${ }^{1} \mathbb{D}$, Muskhazli Mustafa ${ }^{2}$, \\ Mohamed Hamdy Elseknidy ${ }^{3}$ iD and Angham Ali Mohammed ${ }^{1}$
}

check for updates

Citation: Saad, A.H.; Nahazanan, H.; Yusoff, Z.B.M.; Mustafa, M.; Elseknidy, M.H.; Mohammed, A.A. Evaluating Biosedimentation for Strength Improvement in Acidic Soil. Appl. Sci. 2021, 11, 10817. https:// doi.org/10.3390/app112210817

Academic Editor: Daniel Dias

Received: 29 September 2021

Accepted: 1 November 2021

Published: 16 November 2021

Publisher's Note: MDPI stays neutral with regard to jurisdictional claims in published maps and institutional affiliations.

Copyright: (c) 2021 by the authors. Licensee MDPI, Basel, Switzerland. This article is an open access article distributed under the terms and conditions of the Creative Commons Attribution (CC BY) license (https:// creativecommons.org/licenses/by/ $4.0 /)$.
1 Department of Civil Engineering, Faculty of Engineering, Universiti Putra Malaysia, Serdang 43400, Malaysia; ahhassaad@gmail.com (A.H.S.); zmy@upm.edu.my (Z.B.M.Y.); nane.91912828@gmail.com (A.A.M.)

2 Department of Biology, Faculty of Science, Universiti Putra Malaysia, Serdang 43400, Malaysia; muskhazli@upm.edu.my

3 Department of Chemical and Environmental Engineering, Faculty of Engineering, Universiti Putra Malaysia, Serdang 43400, Malaysia; mhhse@outlook.com

* Correspondence: n_haslinda@upm.edu.my

\begin{abstract}
Marine clay soils are problematic soils in the construction industry when they are subjected to construction loads. When these soils are loaded, they lose their structure. This leads to the soil being unable to withstand loads of any magnitude without exhibiting significant, permanent deformations. In order to stabilize the marine soil, new methods for soil improvement were built upon biogrouting by incorporating physical, biological and chemical treatments into the soil. However, the biggest challenge of this method is the bacteria migration through the soil medium. To overcome this issue, the electrokinetic phenomenon can be utilized alongside biogrouting to prevent the bacteria migration. In this regard, the present study applied electrobiogrouting stabilization to investigate the improvement of acidic marine clay soil with a $\mathrm{pH}$ of 3.69. To accomplish this, two large-scale physical models with dimensions of $500 \times 300 \times 1200 \mathrm{~mm}$ were fabricated to examine the influence of two different treated distances between the inlet and outlet-450 $\mathrm{mm}$ (D45) and $600 \mathrm{~mm}$ (D60)—on the stability of the treated soil. It was observed that the shear strength of the treated soil improved significantly. The shear strength at the D45 treated distance increased from $3.65 \mathrm{kPa}$ (untreated soil) to $28.14 \mathrm{kPa}$ (treated soil). However, the strength increased by increasing the treated distance. In addition, compressibility and soil electrical conductivity were reduced significantly, and the Atterberg limits were significantly enhanced from $\mathrm{OH}$ to OL. The reasons for the enhancement of treated soil were the formation of $\mathrm{CaCO}_{3}$, which filled the soil voids, and that the water content was reduced. To address issues with marine clay soil, this study aims to minimize the high cost of a special foundation system and the use of non-environmentally friendly materials such as calcium-based binders, aside from the reduction of deformations caused by loading. The findings of this study can be used for acidic soils and the improvement of soil's geotechnical behavior in general.
\end{abstract}

Keywords: biomineralization; Bacillus pasteurii; marine clay; MICP; soil improvement; acidic soil; soil treatment

\section{Introduction}

Marine clay soil is a type of soil that results from the weathering and erosion of limestone or dolomite, which contains a high content of magnesium, calcium and iron. This soil has high water content and soluble salt that makes it difficult for concrete to set and is porous. They regularly plunge to huge depths of more than $30 \mathrm{~m}$, as shown in Figure 1 [1]. Due to its high-water content [2] and a high amount of organic materials that can exceed $10.0 \%$ of the total dry weight [3], it has low undrained shear strength. Additionally, marine clay soils are a thixotropic substance, meaning that when the water content increases, the thixotropy strength ratio increases [4]. Moreover, acidic clay soils with pH levels less than 4.0 show a considerable loss in shear strength [5]. As a result, significant settling 
occurs both before and after construction [2,6]. Thus, several treatment approaches using lime [7], basalt fibers [8] and biomineralization [9] have been emphasized and oriented toward the enhancement of "environmental soil treatment" that is ecologically friendly and resource-efficient over previous procedures [10].

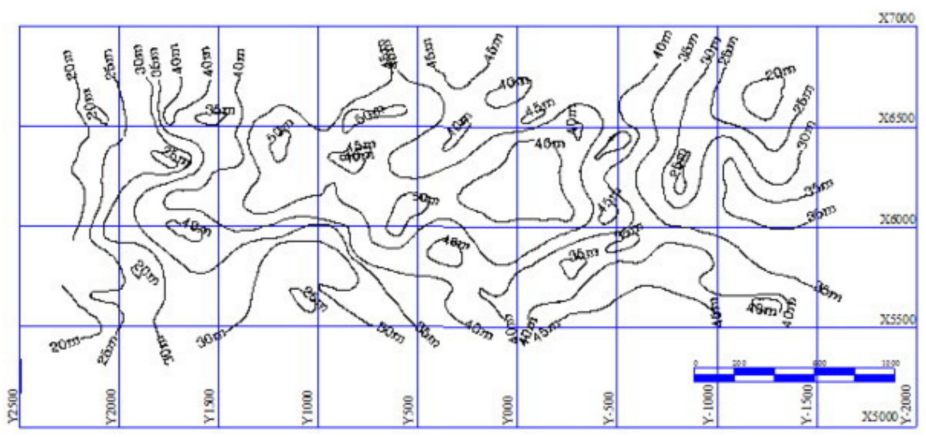

Figure 1. Typical isoline showing marine clay's total thickness [1].

In this respect, biomineralization treatment is one of the numerous environmentally friendly and cost-effective soil improvement strategies that may be used to reinforce weak soils without requiring their replacement or the deployment of a special foundation system $[7,11]$. Microbially induced carbonate precipitation (MICP) was studied to treat weak and loose soils, including a 7-m sand column [10], an upscaling sand treatment beneath footing [12] and a 15-cm clay specimen [13]. For MICP, species of the Bacillus family have the ability to precipitate calcium carbonate $\left(\mathrm{CaCO}_{3}\right)$ by the hydrolysis of urea $\left(\mathrm{CO}\left(\mathrm{NH}_{2}\right)_{2}\right)$ into ammonium $\left(\mathrm{NH}_{4}{ }^{+}\right)$and carbonate $\left(\mathrm{CO}_{3}{ }^{2-}\right)$ ions $[14,15]$. They result in an increase in the $\mathrm{pH}$ level of their cell contents due to the precipitation ability of calcium carbonate $\left(\mathrm{CaCO}_{3}\right)$ in the surrounding microenvironment [16]. The following are the reaction equations $[17,18]$ :

$$
\mathrm{CO}\left(\mathrm{NH}_{2}\right)_{2}+\mathrm{H}_{2} \mathrm{O} \rightarrow 2 \mathrm{NH}_{3}+\mathrm{CO}_{2}
$$

Ammonia $\left(\mathrm{NH}_{3}\right)$ and dissolved inorganic carbon are generated in large amounts by the urease enzyme. Meanwhile, the $\mathrm{pH}$ rises, and the production of ammonia $\left(\mathrm{NH}_{3}\right)$ and dissolved inorganic carbon continues until the urea $\left(\mathrm{CO}\left(\mathrm{NH}_{2}\right)_{2}\right)$ reduces dramatically:

$$
\begin{gathered}
2 \mathrm{NH}_{3}+2 \mathrm{H}_{2} \mathrm{O} \rightarrow 2 \mathrm{NH}_{4}^{+}+2 \mathrm{OH} \\
2 \mathrm{OH}^{-}+\mathrm{CO}_{2} \rightleftharpoons \mathrm{HCO}_{3}^{-}+\mathrm{OH}^{-} \rightleftharpoons \mathrm{CO}_{3}^{-}+\mathrm{H}_{2} \mathrm{O}
\end{gathered}
$$

Alkalinity accumulates with the hydrolysis reaction within bacterial cells:

$$
\text { Cell-Ca }{ }^{2+-}+\mathrm{CO}_{3}{ }^{-} \rightarrow \text { Cell- } \mathrm{CaCO}_{3}
$$

Sporosarcina pasteurii, also known as Bacillus pasteurii [18], is a bacillus family bacterium that produces urease enzymes intracellularly. S. pasteurii is an aerobic endosporeforming soil bacterium with a diameter of $0.5-1.2 \mu \mathrm{m}$ and a length of $1.3-4.0 \mu \mathrm{m}$ [19]. It can also survive in extremely alkaline ( $\mathrm{pH} 10)$ circumstances, making it a relevant agent source for the MICP phenomena [20,21]. Sporosarcina pasteurii, on the other hand, has a peak activity in urease enzyme synthesis in $\mathrm{pH}$ ranges from 8 to 9 [22-24], while precipitation requires a $\mathrm{pH}$ of 9 [25]. Sporosarcina pasteurii also possesses a mechanical pressure resistance of $0.50 \mathrm{~J} / \mathrm{cm}^{3}$ [26]. In general, the precipitation rate of calcium carbonates $\left(\mathrm{CaCO}_{3}\right)$ during the MICP phenomenon is influenced by the bacterial type, cell concentrations, the $\mathrm{pH}$ value of the surrounding microenvironment, calcium concentration, urea concentration, temperature and humidity $[27,28]$.

Soil treatment with the MICP phenomenon increased the strength by up to $570 \mathrm{kPa}$ for sand soil [10] and $92 \mathrm{kPa}$ for clay soil [29], with the carbonate concentration up to 
$60 \mathrm{~kg} / \mathrm{m}^{3}$ of soil specimen [10]. The period of treatment has a minor impact on clay treatment, as evidenced by the fact that the calcium carbonate $\left(\mathrm{CaCO}_{3}\right)$ content for 14 days of treatment was $6 \%$ greater than the calcium carbonate $\left(\mathrm{CaCO}_{3}\right)$ content for 7 days [29]. Laboratory investigations revealed that the calcium carbonate concentration improved the soil's hydraulic and mechanical properties, with a reduction in the permeability, void ratio, liquid limit, plastic limit and collapse index [30,31]. As a result, there was improved structural stability, performance and deformability [32].

Electrokinetic treatment efficiently resists the zeta potential phenomena which is caused by the negative charged surface of the clay and the low hydraulic conductivity [33], where the soil saturation level has a large impact on electrokinetic effectiveness [34,35]. In addition to that, it was used to improve surcharge preloading consolidation in the clay [36,37]. A pH gradient was created across the electrodes, and electrical conductivity was increased [37]. These benefits were employed to treat soils in conjunction with biomineralization [38]. Furthermore, electrokinetic treatment employing the MICP phenomenon increased the strength of soft clay by up to 10 times, with an associated calcium carbonate $\left(\mathrm{CaCO}_{3}\right)$ concentration of $10-16 \%$ of the soil specimen [39] as specialized techniques, and materials which requires substantial and considerable development [40,41].

In this regard, the present study aims to conduct electrokinetic (EK) stabilization of soft acidic soil using the MICP phenomenon on a large-scale specimen to enhance the physical properties of marine clay soil.

\section{Materials and Methods}

\subsection{Bacterial Strain Preparation}

In this study, Bacillus pasteurii bacteria (ATCC-6453) were utilized and harvested using NH4-YE (ATCC Medium 1376) medium, with the following ingredients produced for $1 \mathrm{~L}$. In $200 \mathrm{~mL}$ of desalinated water, $10 \mathrm{~g}$ ammonium sulphate was dissolved, $20 \mathrm{~g}$ yeast extract was dissolved in $200 \mathrm{~mL}$ desalinated water, and $0.13 \mathrm{M}$ Tris buffer $\left(\mathrm{C}_{4} \mathrm{H}_{11} \mathrm{NO}_{3}\right)$ was dissolved in $600 \mathrm{~mL}$ desalinated water. The three components were autoclaved individually for $20 \mathrm{~min}$ at $121{ }^{\circ} \mathrm{C}$ to sterilize them. After cooling, each component was mixed in an Erlenmeyer flask. The $\mathrm{pH}$ of the medium was determined to be 9.0, which is ideal for Bacillus pasteurii growth. The bacteria were then transferred to the broth in an incubator shaker set at $30^{\circ} \mathrm{C}$ with $200 \mathrm{rpm}$ shaking, and the Erlenmeyer flask was sealed for aerobic reduplication. The broth changed into a turbid dark yellow solution after $24-48 \mathrm{~h}$, as illustrated in Figure 2, with the desired cell number for the bacterial concentration being $2.0 \times 10^{7}$ cells $/ \mathrm{mL}$.

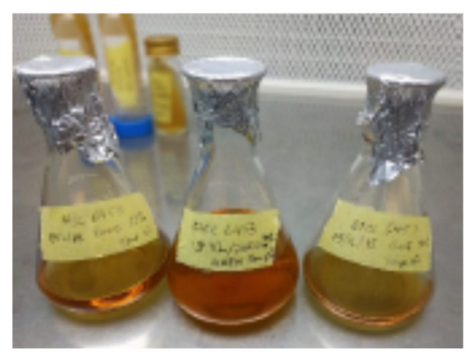

(a)

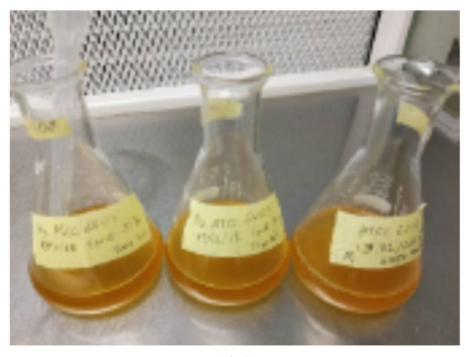

(b)

Figure 2. Bacterial broth (a) before culturing and (b) after $24-48 \mathrm{~h}$ in the incubator.

\subsection{Soil Sampling}

The soil type used in the study was chosen based on the area's history of severe geotechnical issues. Soil samples were obtained from the Malacca riverside at depths ranging from 2.5 to $4.5 \mathrm{~m}$, with the sample site depicted in Figure 3. The groundwater level was $2 \mathrm{~m}$ deep from ground level following the river water level. The samples were kept in accordance with Part-1 1377 of the BSI instructions and recommendations [42], and the soil samples were described in accordance with Part-2 1377 of the BSI instructions [43] 
to avoid uncertainties caused by sample transfer. Table 1 displays the soil's engineering characteristics. A one-dimensional consolidation test revealed soil permeability of $1.88 \times 10^{-7} \mathrm{~cm} / \mathrm{s}$ [44]. With a $\mathrm{pH}$ of 3.69, the soil was very acidic. As indicated in Table 2, the samples were also analyzed for X-ray fluorescence (XRF) to determine the chemical composition of the soil.

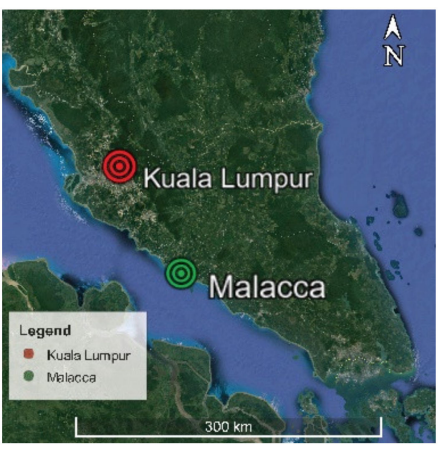

(a)

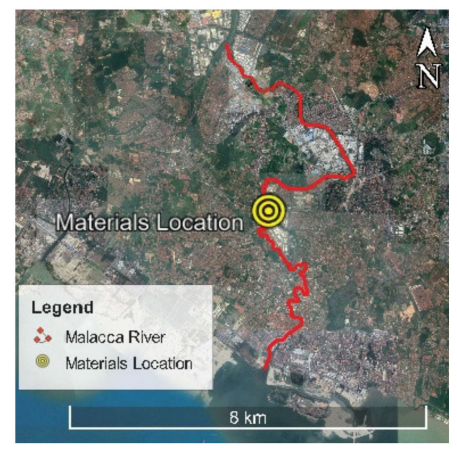

(b)

Figure 3. (a) Location of Malacca on the Peninsular Malaysia map and (b) location of the sampling site for marine clay soil at Malacca River in Malaysia.

Table 1. Engineering characteristics of the soil samples.

\begin{tabular}{cc}
\hline Properties (Unit) & Value \\
\hline Specific gravity Gs & 2.57 \\
Liquid limit (\%) & 63.66 \\
Plastic limit $(\%)$ & 32.57 \\
Plasticity index $(\%)$ & 31.09 \\
Hydraulic conductivity $(\mathrm{cm} / \mathrm{s})$ & $1.88 \times 10^{-7}$ \\
$\gamma_{\mathrm{d}}\left(\mathrm{kg} / \mathrm{cm}^{3}\right)$ & 945 \\
$\mathrm{pH}$ & 3.69 \\
Clay $(\%)$ & 47.7 \\
Mineral composition & Quartz, kaolinite and illite \\
Undrained shear strength $(\mathrm{kPa})$ & 3.65 \\
Water content $(\%)$ & 67 \\
Organic content & $2.15 \%$ \\
\hline
\end{tabular}

Table 2. Chemical composition of the soil samples.

\begin{tabular}{ccccccc}
\hline Compound & $\mathrm{SiO}_{2}$ & $\mathrm{Al}_{2} \mathrm{O}_{3}$ & $\mathrm{Fe}_{2} \mathrm{O}_{3}$ & $\mathrm{~K}_{2} \mathrm{O}$ & $\mathrm{SO}_{3}$ & $\mathrm{MgO}$ \\
\hline Percentage (\%) & 56.23 & 22.81 & 11.29 & 2.82 & 1.92 & 1.55 \\
\hline
\end{tabular}

\subsection{Biosedimentation Procedure}

The physical model dimensions were set in terms of seepage velocity through the targeted soil sample for treatment and longitudinal elongation of the sample to investigate the treatment response with distance and to facilitate the samples' collection. The proposed electrode cell positions were designed to allow the treatment response to be evaluated along the flow direction as well as surrounding the electrode containers.

Figure 4 shows the dimensions of the used container. Acrylic glass was used to construct the set-up, which contained two specimens measuring $450 \mathrm{~mm}$ and $600 \mathrm{~mm}$ in length. In addition, two chambers of acrylic glass were attached within the container, allowing it to function as an electrolyte solution holder. Each chamber had a perforated wall with two fixed graphite bars on one side. The flow between the two compartments was appropriately allowed. Moreover, to regulate the $\mathrm{pH}$ value, a $\mathrm{pH}$ controller system was added in the cathode chamber and was adjusted using a Tris buffer. 


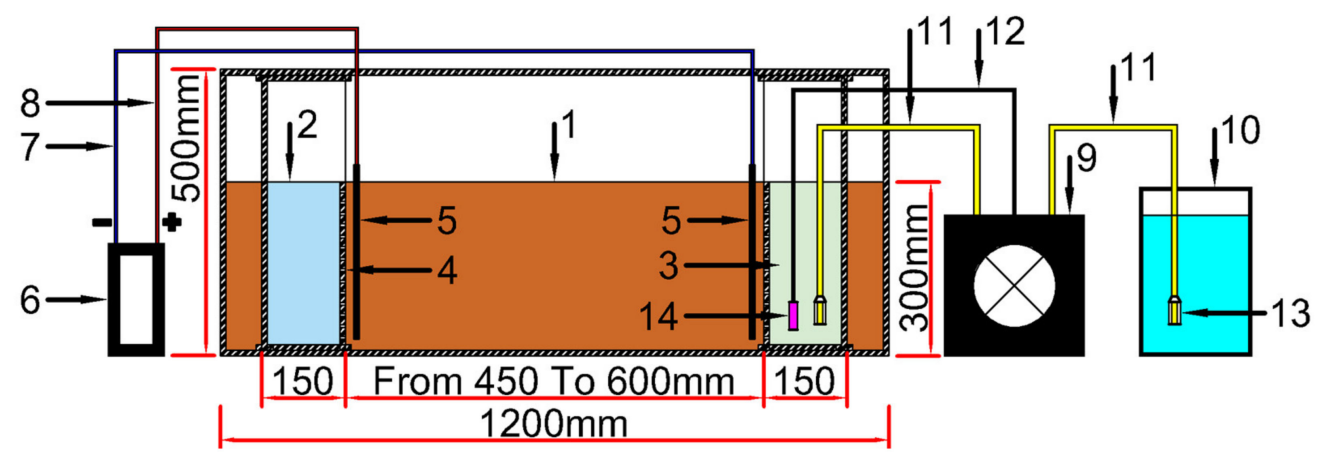

Figure 4. The physical model dimensions show the following: (1) soil sample, (2) anode $\left(\mathrm{CaCl}_{2}\right.$ solution), (3) cathode (urea and bacteria solution), (4) perforated wall of the cell, (5) graphite rod, (6) power supply, (7) wire of positive current, (8) wire of negative current, (9) pump and pH meter, (10) $\mathrm{pH}$ controller solution (tris buffer solution), (11) pump outflow pipe, (12) $\mathrm{pH}$ meter wire, (13) check valve and (14) $\mathrm{pH}$ meter sensor.

For a consistent fluid level inside the system, the surplus fluids created by the electroosmotic flow were manually evacuated. As a result, the specimen did not produce the hydraulic gradient effect. Electro-osmotic flow usually occurs from the anode to the cathode chamber.

A power source with a direct current of $35-40 \mathrm{~V}$ was used in the system. A voltameter was also used to detect the change in voltage potential along the specimen. Vane blades were employed to estimate the shear strengths across the soil sample after 7 treatment days, in line with BSI1377-7-3 [45]. A thermometer was added to the cathode chamber to track temperature changes during the electrokinetic biosedimentation operation. In addition, the water content of each part was measured, and the $\mathrm{CaCO}_{3}$ percent was determined using the EDX test.

As illustrated in Figure 3, to eliminate any ambiguities, two treatment lengths between electrode cells of $600 \mathrm{~mm}$ (D60) and $450 \mathrm{~mm}$ (D45) were investigated using two physical models under the same conditions for the EK effect, treatment period and solutions. As shown in Table 3, the soil samples were analyzed at the end of the treatment period to investigate any micromechanical changes. The experimental work design is shown in Figure 5.

Table 3. Test procedure summary.

\begin{tabular}{ccccc}
\hline No. & Code & Activates & Location & Duration \\
\hline 1 & $\mathrm{~A} 1$ & Injection of $\mathrm{CaCO}_{3}$ and $\mathrm{CO}\left(\mathrm{NH}_{2}\right)_{2}$ & Anode chamber & $1-7$ \\
2 & $\mathrm{~A} 2$ & Cultured bacteria injection & Cathode chamber & $1-7$ \\
3 & $\mathrm{~A} 3$ & Electrical potential measurement & Across the specimens & $1-7$ \\
4 & $\mathrm{~A} 4$ & Vane shear test & Across the specimens & 14 \\
5 & $\mathrm{~A} 5$ & Measurement of water content & Across the specimens & 14 \\
6 & $\mathrm{~A} 6$ & Measurement of $\mathrm{CaCO}_{3}$ percent & Across the specimens & 14 \\
\hline
\end{tabular}




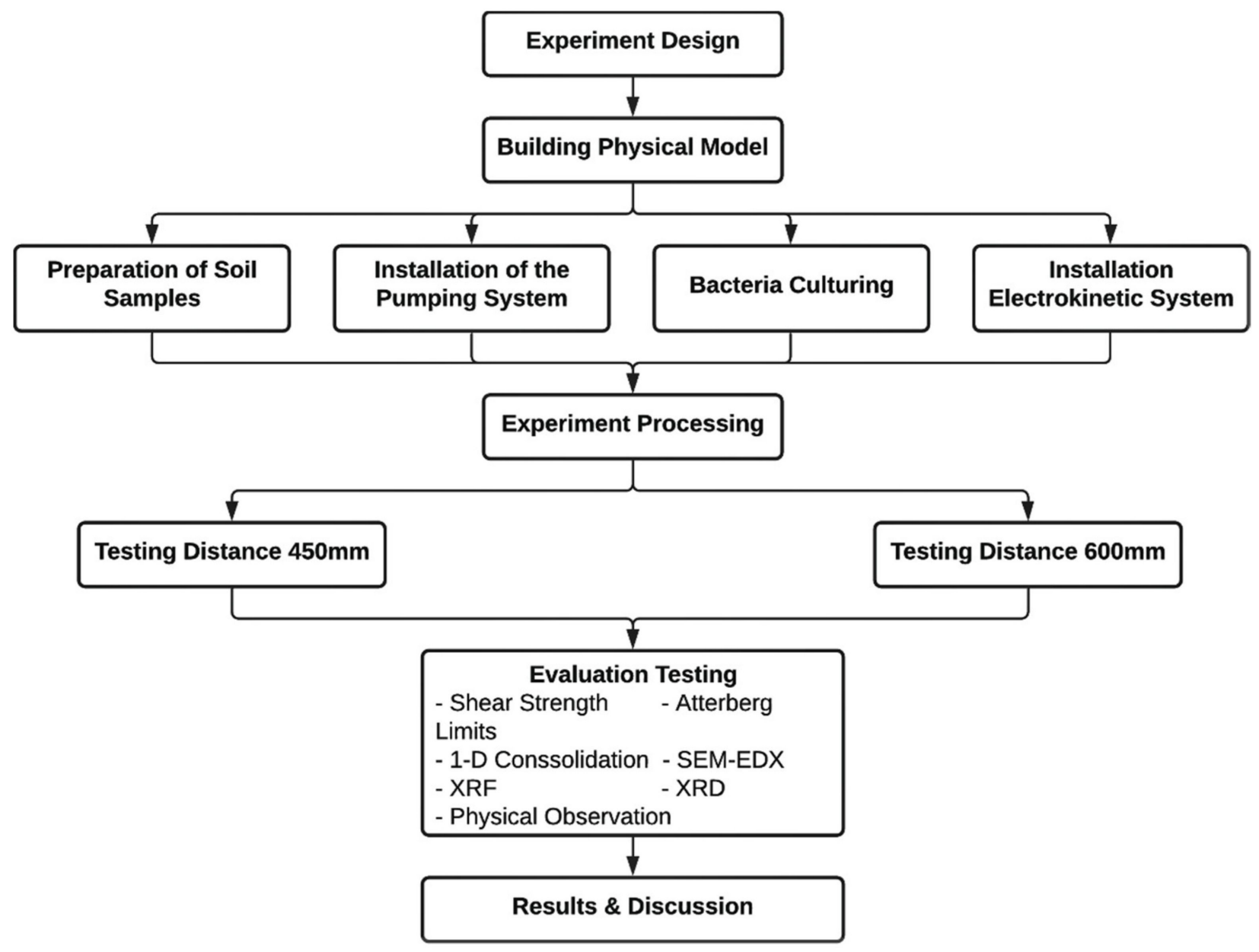

Figure 5. The experimental work's design.

\section{Results and Discussions}

\subsection{Physical Observations}

\subsection{1. $\mathrm{pH}$ Value}

It was found that the $\mathrm{pH}$ value in both electrode cells and along the soil specimen rose over time as the treatment progressed. According to earlier studies [46-50], the $\mathrm{pH}$ of the negative electrode, which had the solution combination of urea $\mathrm{CO}\left(\mathrm{NH}_{2}\right)_{2}$ and bacteria cells, rose slightly during the first 2 days of the treatment and then progressively declined within a $\mathrm{pH}$ value of slightly greater than 9.0. The $\mathrm{pH}$ values of the mediums inside the physical model rose after treatment, regardless of the length of the treated distances, as shown in Figure 6 for D45 $(450 \mathrm{~mm})$ and D60 $(600 \mathrm{~mm})$. The $\mathrm{pH}$ of the soil, on the other hand, was below 6.5, indicating that the bacterial activity inside the soil was restricted and not at its peak. Additionally, the $\mathrm{pH}$ along the specimen dropped as the distance extended by $150 \mathrm{~mm}$, with the $\mathrm{pH}$ value for $\mathrm{D} 45$ being greater than that for D60. The high rate of $\mathrm{NH}_{3}$ and $\mathrm{NH}_{4} \mathrm{OH}$ generation by Bacillus pasteurii bacteria was the cause of the $\mathrm{pH}$ rise, as indicated in chemical Equations (1) and (2), which is consistent with van Paasen's [51] findings. 


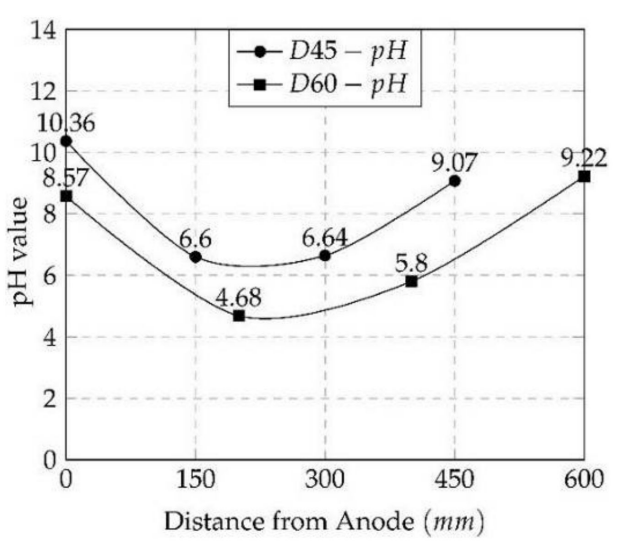

(a)

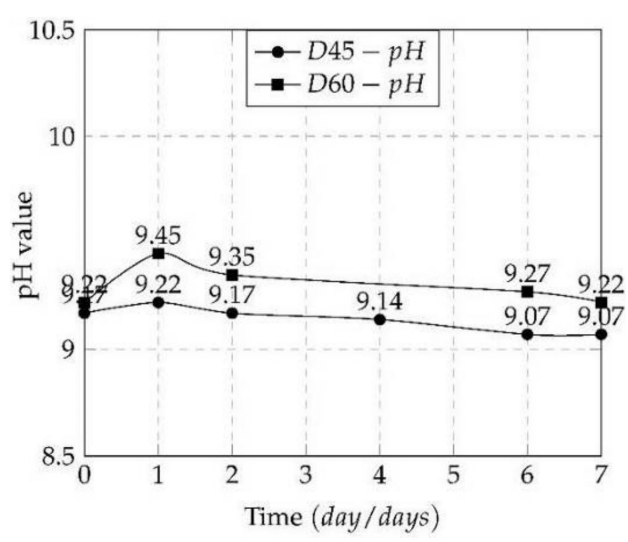

(b)

Figure 6. The pH values for D45 and D60 (a) along the specimen and (b) inside the cathode cell.

\subsubsection{Precipitations}

Regardless of the length of the treated distance, it was observed that the cementitious material calcium carbonate $\left(\mathrm{CaCO}_{3}\right)$ was significantly precipitated in the zone of the anode compared with the zone of the cathode, as shown in Figure 7. The precipitation occurred due to the chemical reaction between calcium carbonates $\left(\mathrm{CaCO}_{3}\right)$ and urea $\left(\mathrm{CO}\left(\mathrm{NH}_{2}\right)_{2}\right)$ in the presence of the urease enzyme produced by Bacillus pasteurii bacteria, as shown in the series of chemical reactions from 1 to 4 , which was infiltrated into the soil under the EK effect, consistent with the findings from prior research [27,30,52,53]. In addition, at the positive electrode cell, the perforated plate was clogged by calcium carbonate $\left(\mathrm{CaCO}_{3}\right)$ precipitation after treatment, as shown in Figure 8.

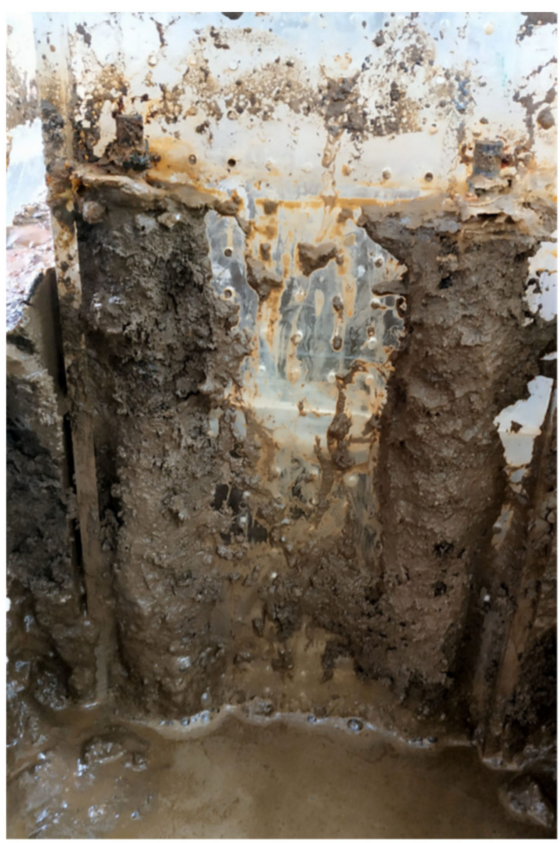

(a)

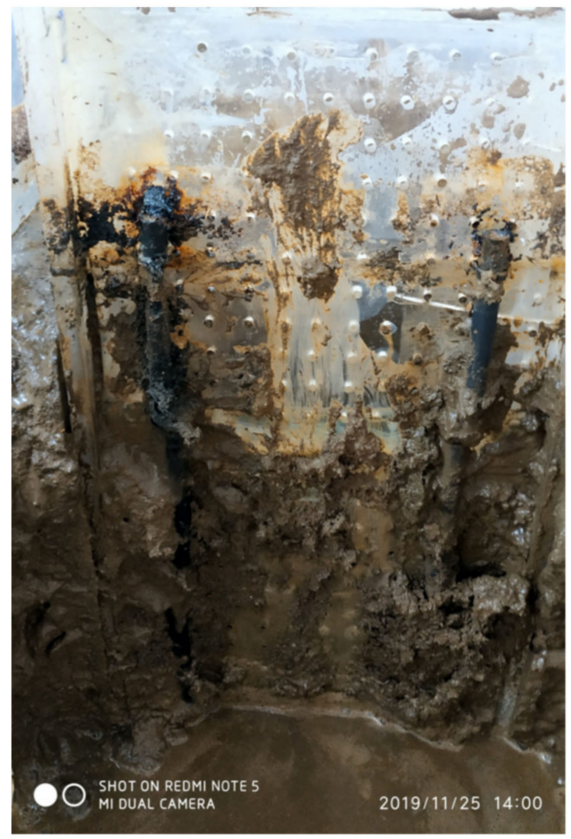

(b)

Figure 7. The precipitation of calcium carbonate $\left(\mathrm{CaCO}_{3}\right)$ at both (a) the anode and $(\mathbf{b})$ the cathode for D60's test. 

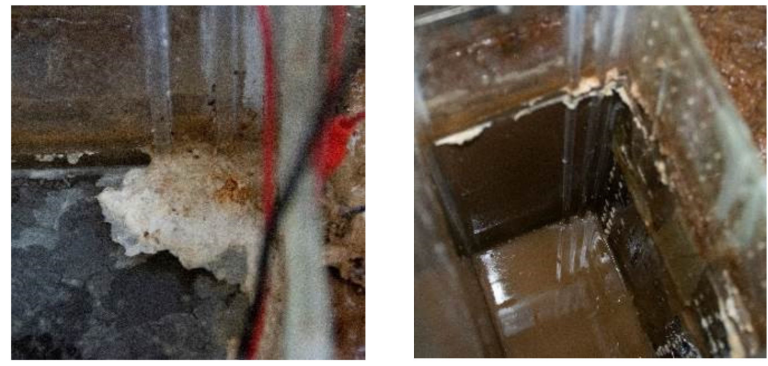

(D45-Anode)

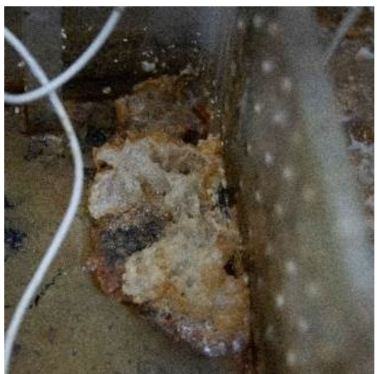

(D60-Anode)
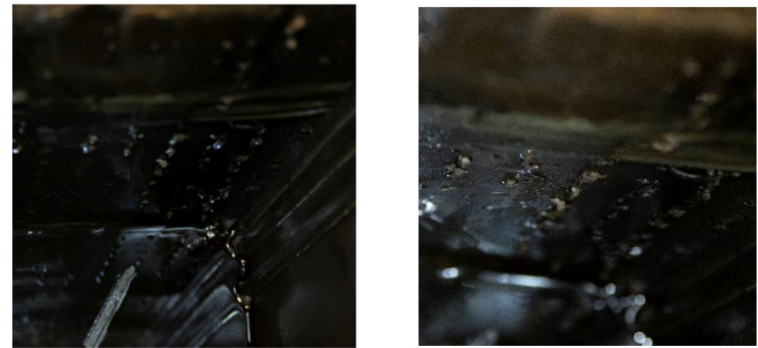

(D45-Cathode)
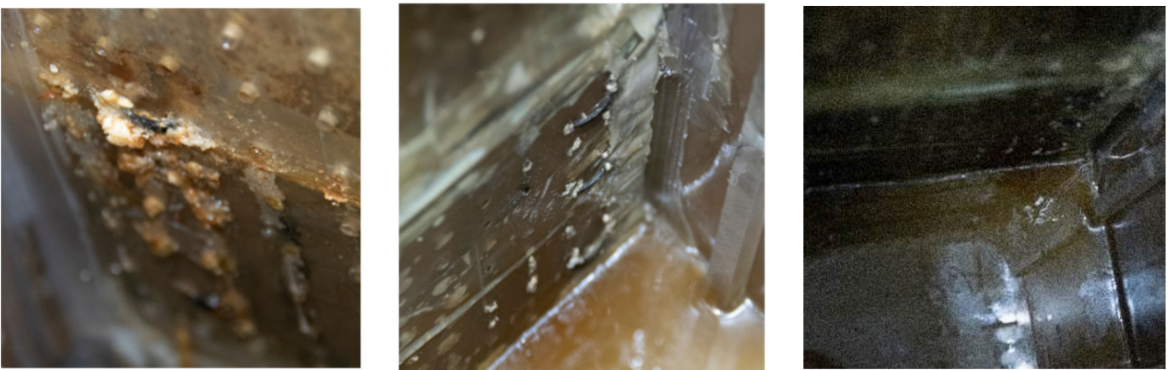

(D60-Anode)

Figure 8. The clogging because of the anode's perforated wall calcium carbonate $\left(\mathrm{CaCO}_{3}\right)$ precipitation for the two treated distances at $450 \mathrm{~mm}$ (D45) and $600 \mathrm{~mm}$ (D60) in the tests.

\subsection{Macro-Mechanical Results}

\subsubsection{Fines Activity}

In general, the Atterberg limits were decreased considerably following treatment, with the liquid limit dropping by about 36\% for both treatment distances D45 and D60 when compared with natural soil (N). In addition, as shown in Figure 9, the fines classification for D45 and D60 had changed from organic clay with high flexibility to that of moderate plasticity. The reasons for this were the buildup of $\mathrm{CaCO}_{3}$ on the surface of the soil particles, as well as the water migration outside the soil specimen due to the electro-kinetic action, as evidenced by earlier research $[37,38]$. In Table 4 , all of the data are tallied and compared to natural soil $(\mathrm{N})$. Table 4 summarizes all of the findings and compares them to natural soil (N).

Plasticity Chart for USCS

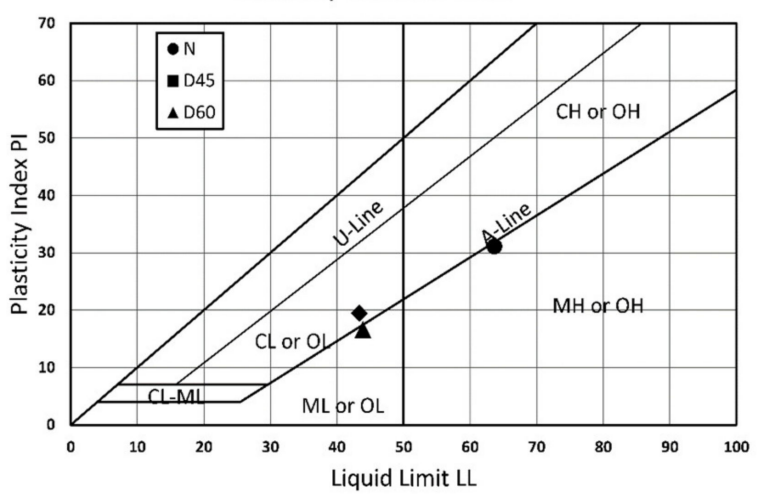

Figure 9. Atterberg limits and soil classification for untreated soil $(\mathrm{N})$ and treated distances of $450 \mathrm{~mm}(\mathrm{D} 45)$ and $600 \mathrm{~mm}$ (D60). 
Table 4. Atterberg limits and soil classification for untreated soil (N) and treated distances of $450 \mathrm{~mm}$ (D45) and $600 \mathrm{~mm}$ (D60).

\begin{tabular}{cccccccc}
\hline $\begin{array}{c}\text { Code } \\
\text { (Unit) }\end{array}$ & $\begin{array}{c}\mathbf{w}_{\mathbf{c}} \\
\mathbf{( \% )}\end{array}$ & $\begin{array}{c}\mathbf{w}_{\text {LL }} \\
\mathbf{( \% )}\end{array}$ & $\begin{array}{c}\mathbf{w}_{\mathbf{P L}} \\
\mathbf{( \% )}\end{array}$ & $\mathbf{P I}$ & $\mathbf{L I}$ & $\mathbf{C I}$ & USCS \\
\hline $\mathrm{N}$ & 67 & 63.66 & 32.57 & 31.1 & 1.151 & -0.101 & OH \\
$\mathrm{D} 45$ & 49.07 & 43.37 & 23.94 & 19.44 & 1.52 & -0.24 & OL \\
$\mathrm{D} 60$ & 48.02 & 43.88 & 27.27 & 16.62 & 1.89 & -0.15 & OL \\
\hline
\end{tabular}

\subsubsection{Soil Compressibility}

The 1-D consolidation test yielded a set of coefficients and indices, which are summarized in Tables 5 and 6 . The consolidation characteristics were considerably improved after D45 treatment compared with D60 treatment. In general, compared with natural soil's compressibility, the soil compressibility decreased substantially following treatment $(\mathrm{N})$. Furthermore, compared with natural soil's permeability, the permeability after treatment increased by eight times for both $\mathrm{D} 45$ and D60. This was due to the buildup of $\mathrm{CaCO}_{3}$ on the soil surface and the dissipation of water outside the soil specimen during the MICP and EK processes, which was observed by Keykha et al. [39].

Table 5. Conducted and derived consolidation parameters for N, D45 and D60.

\begin{tabular}{ccccc}
\hline Code & $\mathbf{C}_{\mathbf{C}}$ & CR & $\mathbf{C}_{\boldsymbol{\alpha} \boldsymbol{\epsilon}}$ & $\mathbf{C}_{\mathbf{r}}$ \\
\hline $\mathrm{N}$ & 0.27995 & 0.10450 & 0.03351 & 0.01462 \\
$\mathrm{D} 45$ & 0.24186 & 0.10555 & 0.03852 & 0.03282 \\
D60 & 0.20796 & 0.09424 & 0.04121 & 0.02371 \\
\hline
\end{tabular}

Table 6. Conducted and derived permeability and compression parameters for N, D45 and D60.

\begin{tabular}{ccccc}
\hline Code & $\mathbf{C}_{\mathbf{V}}$ & $\mathbf{k}$ & $\mathbf{m}_{\mathbf{v}}$ & $\mathbf{a}_{\mathbf{v}}$ \\
\hline $\mathbf{( U n i t )}$ & $\mathbf{( \mathbf { m } ^ { 2 } / \text { year } )}$ & $\mathbf{( m / \mathbf { s } )}$ & $\left.\mathbf{( m}^{\mathbf{2}} / \mathbf{t o n}\right)$ & $\left.\mathbf{( m}^{\mathbf{2}} / \mathbf{t o n}\right)$ \\
\hline $\mathrm{N}$ & 2.55778 & $1.9 \times 10^{9}$ & 0.02916 & 0.07146 \\
$\mathrm{D} 45$ & 8.10157 & $8.2 \times 10^{9}$ & 0.01110 & 0.01792 \\
$\mathrm{D} 60$ & 3.62619 & $6.4 \times 10^{9}$ & 0.01027 & 0.02255 \\
\hline
\end{tabular}

\subsubsection{Specific Gravity and Density}

The soil characteristics of the D45 and D60 soil specimens were considerably improved following treatment, as indicated in Table 7. The bulk density for D45 and D60 rose from $1560 \mathrm{~kg} / \mathrm{m}^{3}$ to $1710 \mathrm{~kg} / \mathrm{m}^{3}$ and $1670 \mathrm{~kg} / \mathrm{m}^{3}$, respectively. For both D45 and D60, the void ratio fell substantially. D60, on the other hand, maintained the same specific gravity of 2.51 as natural soil $(\mathrm{N})$. Furthermore, the modulus of elasticity (Young's modulus) for both D45 and D60 was considerably increased, reaching up to two times that of natural soil $(\mathrm{N})$. That was owing to the filling of soil voids by $\mathrm{CaCO}_{3}$, as well as a reduction in the water content, both of which occurred as a result of the electrokinetic effect, as validated by research $[37,38]$.

Table 7. Specific gravity, density, void ratio, modulus of elasticity and preconsolidation stress for $\mathrm{N}$, D45 and D60 after treatment.

\begin{tabular}{|c|c|c|c|c|c|c|}
\hline Code & $\mathrm{G}_{\mathrm{S}}$ & $\gamma_{\text {wet }}$ & $\gamma_{\text {dry }}$ & $\mathbf{e}_{\mathbf{o}}$ & E & $\mathbf{P}_{\mathbf{c}}^{\prime}$ \\
\hline (Unit) & & $\left(t / m^{2}\right)$ & $\left(t / m^{2}\right)$ & & (kPa) & (kPa) \\
\hline $\mathrm{N}$ & 2.51 & 1.56 & 0.94 & 1.68 & 2130.64 & 42 \\
\hline D45 & 2.63 & 1.71 & 1.15 & 1.29 & 4848.07 & 320 \\
\hline D60 & 2.51 & 1.69 & 1.14 & 1.21 & 4670.79 & 380 \\
\hline
\end{tabular}




\subsubsection{Shear Strength}

The shear strength of the treated soil improved as a result of this technique, which is thought to be related to calcium carbonate precipitation $\left(\mathrm{CaCO}_{3}\right)$. It was observed that the strength of the soil samples changed with the distance between the anode and the cathode, with maximum shear strengths of 28.14 and $14.50 \mathrm{kPa}$ for D45 and D60, respectively, at the anode. Furthermore, as shown in Figure 10, the shear strength fell by as much as $36 \%$ for D45 and $23 \%$ for D60 from the maximum undrained shear strength as the treatment distance increased. This fluctuation in strength corresponded to the rate of calcium carbonate precipitation, with more $\mathrm{CaCO}_{3}$ precipitation resulting in a higher shear strength. Both van Paassan et al. [53] and Keykha et al. [39] agreed that the void ratio was lowered owing to the buildup of $\mathrm{CaCO}_{3}$ inside it and that the water content was considerably reduced by dissipation outside the voids of the soil specimen, which assisted in the shear strength's enhancement.

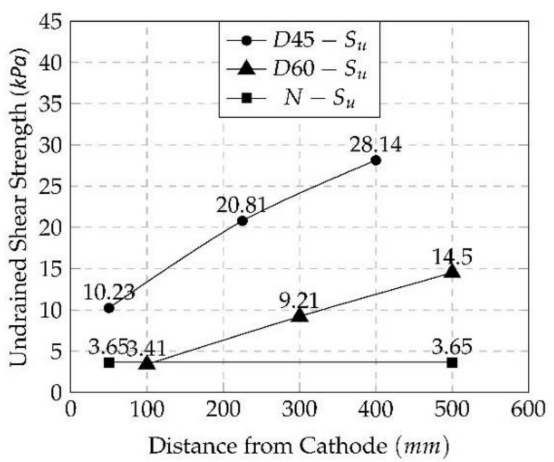

Figure 10. Shear strength after 7 days of biomineralization treatment under the EK method for D45 and D60.

\subsection{Micro-Mechanical Results \\ 3.3.1. XRD Results}

The results of the X-ray diffraction (XRD) analysis showed no changes for the soil specimen mineralogy after the treatment for $\mathrm{D} 45$ compared to natural soil $(\mathrm{N})$, and both were majorly formed by quartz, kaolinite and illite. Because the EK had little effect on the chemical composition and mineralogy of soil particles, it only changed the ions in the solution. Furthermore, the MICP solutions and their precipitation had a minor chemical interaction with the soil minerals. Therefore, it can be concluded that the biomineralization process under the electrokinetic method did not affect the recreation of soil minerals, as shown in Figure 11 with the peaks.

\subsubsection{XRF Results}

The results of X-ray powder fluorescence (XRF) showed that the amount of calcium carbonate $\left(\mathrm{CaCO}_{3}\right)$ rose significantly by $1.18 \%$ of the total weight of the sample, as shown in Table 8 , indicating the effectiveness of the biomineralization process utilizing the electrokinetic technique and the movement of the materials inside the soil specimen. In addition, the calcium carbonate $\left(\mathrm{CaCO}_{3}\right)$ decreased as the distance between the anode and cathode increased from $1.18 \%$ to $0.83 \%$ for D45 and D60, respectively. Furthermore, for the fixed distance between the cathode and anode, the calcium carbonate $\left(\mathrm{CaCO}_{3}\right)$ percentage from the total weight decreased upon getting closer to the cathode, changing from $1.18 \%$ at $400 \mathrm{~mm}$ to $0.12 \%$ at $50 \mathrm{~mm}$ from the cathode cell for D45-1 and D45-3, respectively. 

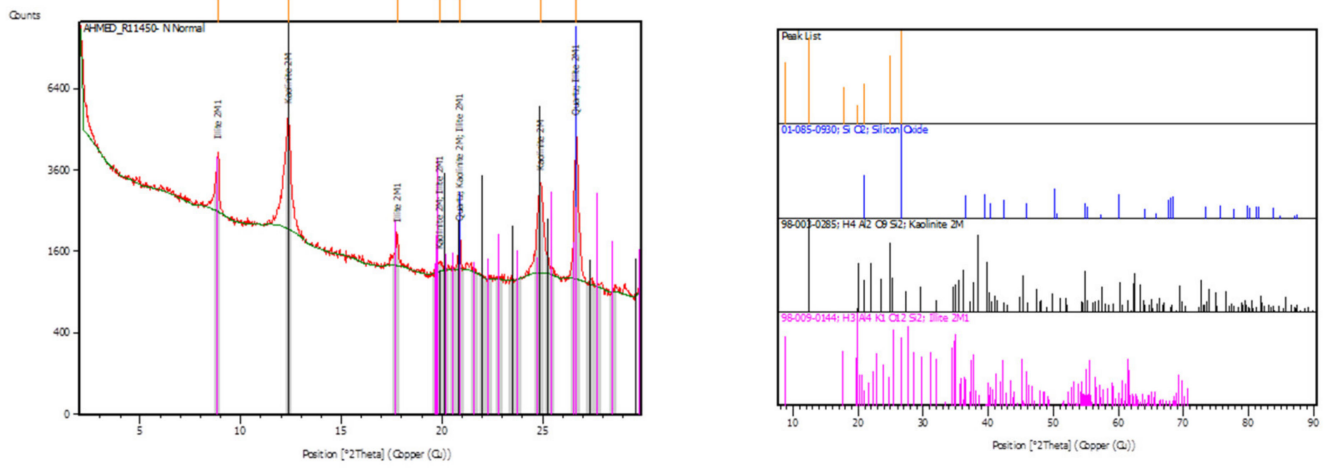

(N)
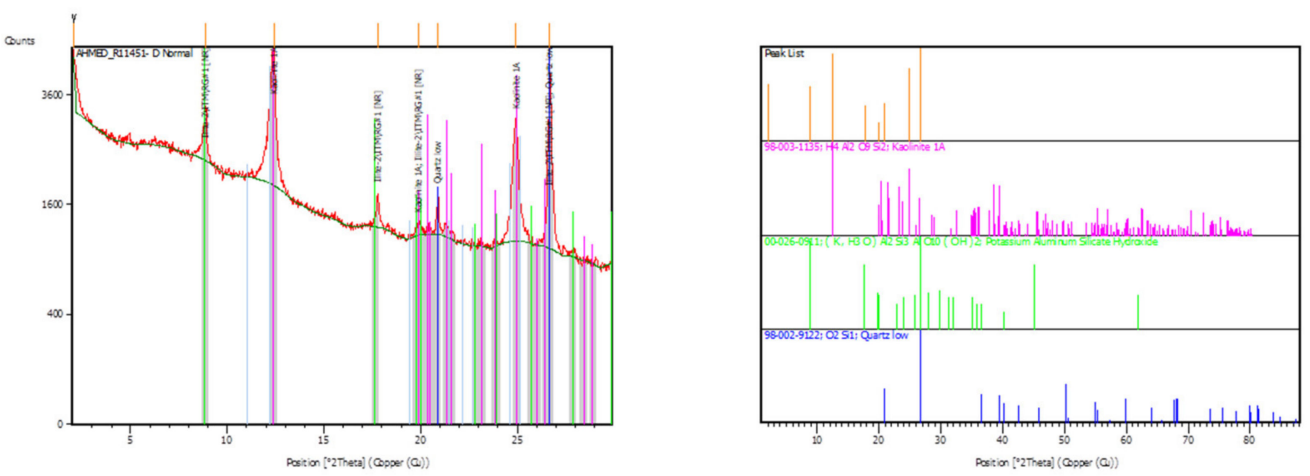

(D45)

Figure 11. XRD results and peaks for both untreated soil (N) and the treated distance of $450 \mathrm{~mm}$ (D45).

Table 8. Chemical composition of untreated soil (N) and treated distances of $450 \mathrm{~mm}(\mathrm{D} 45)$ and $600 \mathrm{~mm}$ (D60) after treatment.

\begin{tabular}{cccccccccc}
\hline Compound & (Unit) & $\mathrm{Al}_{2} \mathbf{O}_{3}$ & $\mathbf{S i O}_{2}$ & $\mathrm{CaCO}_{3}$ & $\mathrm{TiO}_{2}$ & $\mathbf{K}_{\mathbf{2}} \mathbf{O}$ & $\mathbf{S O}_{3}$ & $\mathbf{C l}$ & Others \\
\hline $\mathrm{N}$ & $(\%)$ & 27.88 & 63.46 & - & - & - & 1.6 & - & 7.06 \\
$\mathrm{D} 45-1$ & $(\%)$ & 28.78 & 62.97 & 1.18 & 0.35 & - & - & - & 6.72 \\
$\mathrm{D} 45-2$ & $(\%)$ & 31.08 & 58.05 & 0.71 & - & - & 2.47 & - & 7.69 \\
$\mathrm{D} 45-3$ & $(\%)$ & 31.02 & 61.22 & 0.12 & 0.56 & - & - & - & 7.08 \\
$\mathrm{D} 60$ & $(\%)$ & 29.14 & 58.24 & 0.83 & - & - & - & - & 11.79 \\
\hline
\end{tabular}

\subsubsection{SEM-EDX Results}

The coating rate of the interfacial of clay particles rose when the SEM sample was collected closer to the anode cell, indicating that the precipitated quantity of calcium carbonate $\left(\mathrm{CaCO}_{3}\right)$ covered the interfacial of the clay particles. Following the coating rate, the edges of the clay layers sharpened and grew more interlocked. Figure 12 illustrates the calcium carbonate $\left(\mathrm{CaCO}_{3}\right)$ coating dispersion in the mapping picture for D60. Figure $13 \mathrm{c}$, at a distance of $50 \mathrm{~mm}$ from the cathode cell for D45, shows that the soil particles got smaller as the amount of calcium carbonate $\left(\mathrm{CaCO}_{3}\right)$ precipitated decreased. Furthermore, as demonstrated in Figures 13a and 12d for D45 and D60, respectively, the quantity of calcium carbonate $\left(\mathrm{CaCO}_{3}\right)$ precipitated increased as the treatment distance between the cathode and anode cells decreased. To explain this, upon getting further away from the anode and the direction of ion migration within the soil specimen during the treatment process, the range of the EK effect decreased [37,38]. 

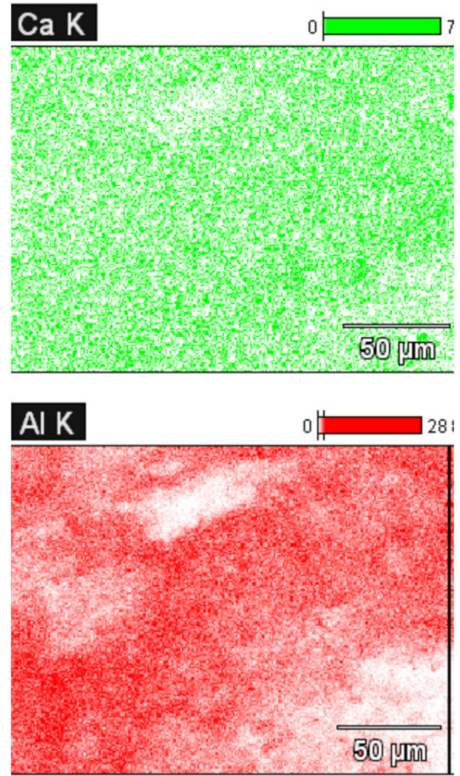

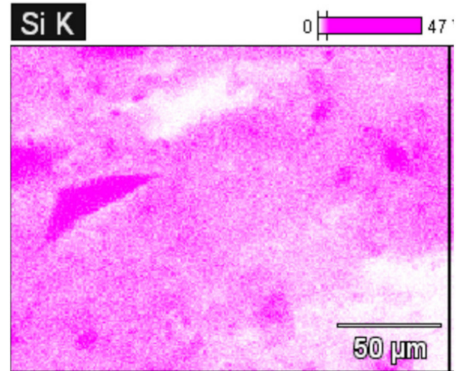

${ }_{18871}+{ }_{18535}$

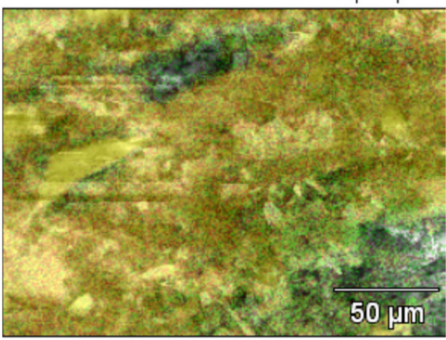

Figure 12. SEM-EDX mapping for a treated distance of $600 \mathrm{~mm}$ (D60), showing $\mathrm{Ca}, \mathrm{Si}, \mathrm{Al}$ and their overlapping mapping with the SEM image.

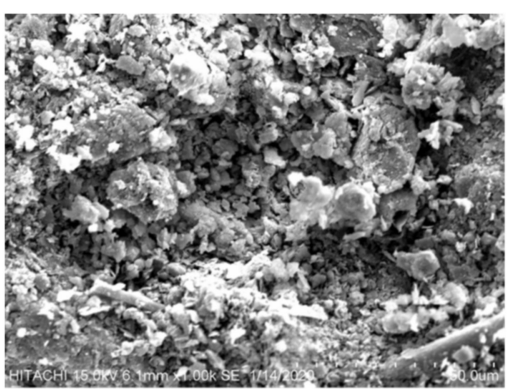

(a)

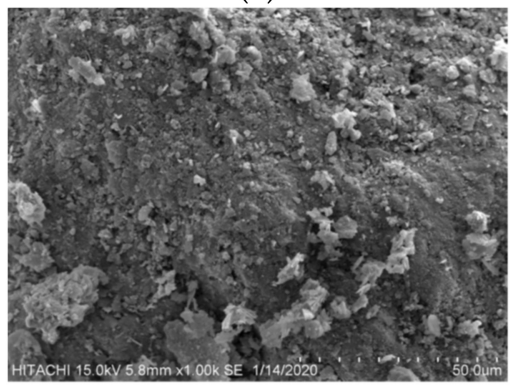

(c)

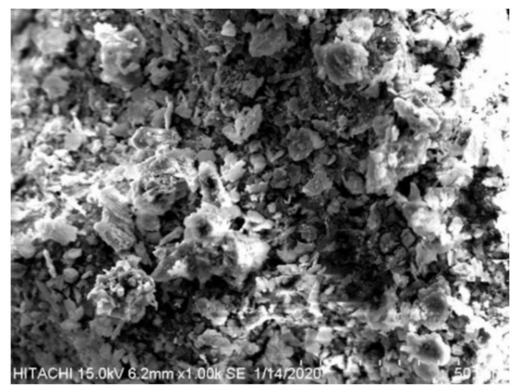

(b)

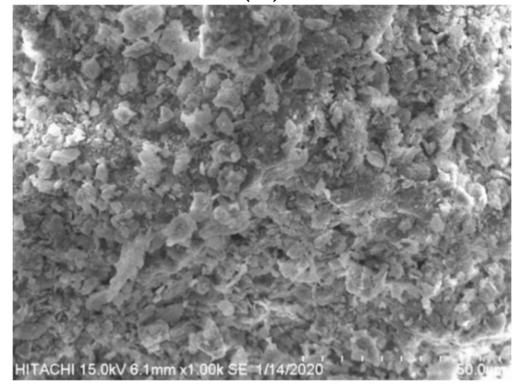

(d)

Figure 13. SEM-EDX results for a treated distance of $450 \mathrm{~mm}$ (D45) at (a) $400 \mathrm{~mm}$, (b) $225 \mathrm{~mm}$ and (c) $50 \mathrm{~mm}$, as well as for (d) a treated distance of $600 \mathrm{~mm}(\mathrm{D} 60)$ at $500 \mathrm{~mm}$.

\subsection{Chemical Observations}

During the treatment, bubbles surrounding the graphite bars were seen to form shortly after the electric current was turned on. Following treatment, the graphite rods at the cathode were found to be considerably eroded, as illustrated in Figure 14. After erosion, the cross-section of graphite rods was $25 \%$ of the initial cross-section. The negative electrode liquid's color also changed to black, as seen in Figure 15. Furthermore, as the depth of the solution increased, the color of the solution became darker. This was due to the heavy weight of the chemical compounds produced from the chemical reaction with the graphite rod under the EK effect. 


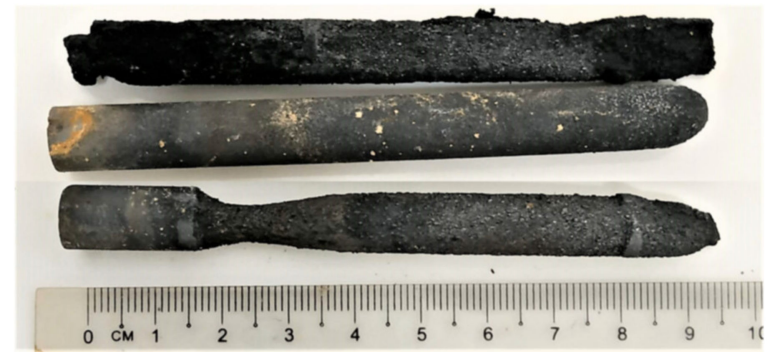

(a)

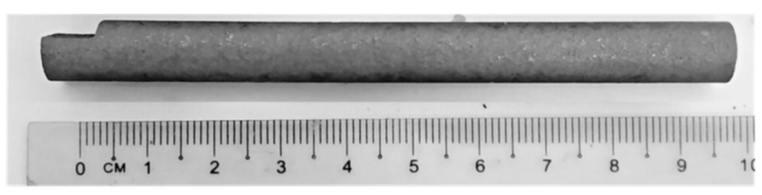

(b)

Figure 14. Erosion of the graphite bars (a) after treatment compared with (b) the initial condition.

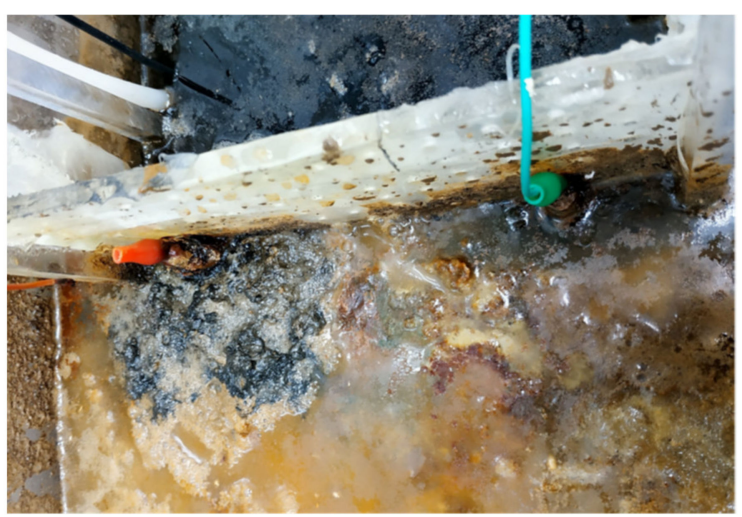

Figure 15. The negative electrode solution and the zone around the graphite bars are colored black after treatment.

\section{Conclusions}

Substantial construction projects impact the economy, society and the environment over their life cycles [54], where weak soil stability plays a key role in construction sustainability. As marine clay is a weak soil, it is normally found in coastal regions around the world, such as; seas, lakes, ocean shores and riverbanks. It usually extends to enormous depths underneath the earth's surface. It is also notorious for being involved in landslides and large settlements. Special foundation systems, such as piles or soil replacements, are usually costly solutions compared with the proposed structure cost itself and require high quality control to meet their purpose: balance the essentials to be generated among the economic and environmental aspects [54,55]. Conducting electrokinetic (EK) stabilization of soft acidic soil using the MICP phenomenon on a large-scale specimen is very important for improving soil environmentally. Nevertheless, no study has measured or assessed this previously mentioned experiment that encourages soil improvement adoption. This study aimed to cover this gap by highlighting the use of electrokinetic (EK) stabilization of soft acidic soil using the MICP for achieving soil project sustainability.

The feasibility of large-scale marine clay soil treatment was examined, where the following conclusions were drawn:

1. For the distance effect, as the distance increased by $150 \mathrm{~mm}$ between the two electrode cells, the shear strength decreased by $50 \%$, where the maximum undrained shear strength was achieved by D45, which was $28.14 \mathrm{kPa}$, and $14.50 \mathrm{kPa}$ was achieved for D60 at the anode cell.

2. Furthermore, the variation in shear strength after treatment along the soil specimen from the anode to the cathode was significant, where it decreased gradually until it reached the minimum values at the cathode. The minimum values were lowered by more than a half of the maximum values for both D45 and D60.

3. For the compressibility, both D45 and D60's compressibility indices were reduced significantly compared with natural soil $(\mathrm{N})$, where for the fines activity, all Atterberg 
limits were also significantly enhanced, and the soil changed from $\mathrm{OH}$ to OL for D45 and D60. Therefore, the treated soil could sustain loads with lesser deformations compared with non-treated soils.

4. In addition, the $\mathrm{pH}$ value increased gradually and remained higher than 9.0, which guaranteed bacterial activity during the treatment process. This was due to the high rate of bacterial activity in the first $48 \mathrm{~h}$ in the production of $\mathrm{NH}_{3}$.

5. After treatment for both the D45 and D60 specimens, the perforated walls were clogged at both the anode and cathode but were more significant for the anode. This was a result of the maximum accumulation of $\mathrm{CaCO}_{3}$ precipitation at the anode side compared with the cathode side by at least 10 times.

6. For soil electric conductivity, it was observed that the soil resistance increased gradually until the end of the treatment from $25-30 \mathrm{~V}$ to $55-60 \mathrm{~V}$. This reflected the increase in soil density, as the electrical potential deference increased significantly after treatment.

7. XRF detected that the precipitation of calcium carbonate $\left(\mathrm{CaCO}_{3}\right)$ was achieved for both D45 and D60, with higher precipitation for D45. However, XRD detected that the soil mineralogy remained the same after EK treatment with biomineralization. The precipitation was $1.18 \%$ of the specimen's total weight for D45 and $0.83 \%$ for D60.

8. SEM-EDX showed soil texture enhancement, and mapping images showed the coating of particles by calcium carbonate $\left(\mathrm{CaCO}_{3}\right)$, which was the reason for void reduction and strength enhancement after treatment, and therefore the soil properties were enhanced in terms of compressibility.

Based on the results, biocementitiousness for acidic soil helped for shear strength improvement and soil compressibility, which led to a significant reduction in deformations caused by different loading processes. Accordingly, this method could help in strengthening weak clayey or acidic soils even without replacement. That aside, it would reduce the construction time of foundations and limit the costs of special foundation systems significantly. In addition, the method of treatment in this article helps with the reduction of soil permeability, which could help with the enhancement of water structure stability by increasing the hydraulic gradient underneath the water structures.

The effect of changing the urea injecting location along the soil specimen is to be studied in future research to demonstrate its effect on the treatment process and MICP rate. In addition, proposing new injection methods could be covered in prospective studies that would help increase the MICP treatment range and quality.

Author Contributions: Conceptualization, A.H.S. and H.N.; methodology, A.H.S., H.N. and M.M.; validation, A.H.S., H.N., Z.B.M.Y. and M.M.; formal analysis, A.H.S. and H.N.; investigation, A.H.S.; resources, H.N.; data curation, A.H.S.; writing-original draft preparation, A.H.S. and H.N.; writing-review and editing, A.H.S., H.N., Z.B.M.Y., M.M., M.H.E. and A.A.M.; supervision, H.N., Z.B.M.Y. and M.M; project administration, H.N.; funding acquisition, H.N. All authors have read and agreed to the published version of the manuscript.

Funding: This research was funded by the Putra Grant Scheme (Geran Putra): GP/2018/9635200, Universiti Putra Malaysia.

Institutional Review Board Statement: Not applicable.

Informed Consent Statement: Not applicable.

Data Availability Statement: All relevant data are within the manuscript.

Acknowledgments: The authors acknowledge the technical support by Mohd Razali and Azleen Ahmad in both the geotechnical laboratory and biology laboratory of Universiti Putra Malaysia.

Conflicts of Interest: The authors declare no conflict of interest. 


\section{References}

1. Bo, M.W.; Arulrajah, A.; Sukmak, P.; Horpibulsuk, S. Mineralogy and geotechnical properties of Singapore marine clay at Changi. Soils Found. 2015, 55, 600-613. [CrossRef]

2. Indraratna, B. Interpretation of field and laboratory shear strength data of a soft marine clay. Q. J. Eng. Geol. Hydrogeol. 2007, 30, 197-203. [CrossRef]

3. Lu, T.; Bryant, W.R. Comparison of vane shear and fall cone strengths of soft marine clay. Mar. Georesour. Geotechnol. 1997, 15, 67-82. [CrossRef]

4. Yang, S.; Andersen, K.H. Thixotropy of Marine Clays. Geotech. Test. J. 2016, 39, 331-339. [CrossRef]

5. Gratchev, I.; Towhata, I. Stress-strain characteristics of two natural soils subjected to long-term acidic contamination. Soils Found. 2013, 53, 469-476. [CrossRef]

6. Wu, H.N.; Huang, R.Q.; Sun, W.J.; Shen, S.L.; Xu, Y.S.; Liu, Y.B.; Du, S.J. Leaking behavior of shield tunnels under the Huangpu River of Shanghai with induced hazards. Nat. Hazards 2014, 70, 1115-1132. [CrossRef]

7. Saadat, M.; Bayat, M. Prediction of the unconfined compressive strength of stabilised soil by Adaptive Neuro Fuzzy In-ference System (ANFIS) and Non-Linear Regression (NLR). Geomech. Geoeng. 2019, 1-12. [CrossRef]

8. Hadi Sahlabadi, S.; Bayat, M.; Mousivand, M.; Saadat, M. Freeze-Thaw Durability of Cement-Stabilized Soil Reinforced with Polypropylene/Basalt Fibers. J. Mater. Civ. Eng. 2021, 33, 04021232. [CrossRef]

9. Whiffin, V.S.; van Paassen, L.A.; Harkes, M.P. Microbial Carbonate Precipitation as a Soil Improvement Technique. Geomicrobiol. J. 2007, 24, 417-423. [CrossRef]

10. DeJong, J.T.; Soga, K.; Banwart, S.A.; Whalley, W.R.; Ginn, T.R.; Nelson, D.C.; Mortensen, B.M.; Martinez, B.C.; Barkouki, T. Soil engineering in vivo: Harnessing natural biogeochemical systems for sustainable, multi-functional engineering solutions. J. R. Soc. Interface 2011, 8, 1-15. [CrossRef]

11. Choi, S.G.; Chu, J.; Brown, R.C.; Wang, K.; Wen, Z. Sustainable Biocement Production via Microbially Induced Calcium Carbonate Precipitation: Use of Limestone and Acetic Acid Derived from Pyrolysis of Lignocellulosic Biomass. ACS Sustain. Chem. Eng. 2017, 5, 5183-5190. [CrossRef]

12. DeJong, J.T.; Mortensen, B.M.; Martinez, B.C.; Nelson, D.C. Bio-mediated soil improvement. Ecol. Eng. 2010, 36, 197-210. [CrossRef]

13. Keykha, H.; Huat, B.B.K.; Asadi, A. Electro-biogrouting stabilisation of soft soil. Environ. Geotech. 2015, 2, 292-300. [CrossRef]

14. Keykha, H.; Asadi, A.; Huat, B.B.K.; Kawasaki, S. Laboratory Conditions for Maximal Calcium Carbonate Precipitation Induced by Sporosarcina pasteurii and Sporosarcina aquimarina Bacteria. Environ. Geotech. 2018, 6, 1-20. [CrossRef]

15. DeJong, J.T.; Fritzges, M.B.; Nüsslein, K. Microbially Induced Cementation to Control Sand Response to Undrained Shear. J. Geotech. Geoenviron. Eng. 2006, 132, 1381-1392. [CrossRef]

16. Hammes, F.; Boon, N.; de Villiers, J.; Verstraete, W.; Siciliano, S.D. Strain-Specific Ureolytic Microbial Calcium Carbonate Precipitation. Appl. Environ. Microbiol. 2003, 69, 4901-4909. [CrossRef]

17. Achal, V.; Mukherjee, A.; Kumari, D.; Zhang, Q. Biomineralization for sustainable construction-A review of processes and applications. EarthScience Rev. 2015, 148, 1-17. [CrossRef]

18. Li, D.; Tian, K.L.; Zhang, H.L.; Wu, Y.Y.; Nie, K.Y.; Zhang, S.C. Experimental investigation of solidifying desert aeolian sand using microbially induced calcite precipitation. Constr. Build. Mater. 2018, 172, 251-262. [CrossRef]

19. Keykha, H.; Huat, B.B.K.; Asadi, A.; Zareian, M.; Kawasaki, S. Electrokinetic properties of pasteurii and aquimarina bacteria. Environ. Geotech. 2014, 2, 181-188. [CrossRef]

20. Dhami, N.K.; Reddy, M.S.; Mukherjee, A. Biomineralization of calcium carbonates and their engineered applications: A review. Front. Microbiol. 2013, 4, 314. [CrossRef]

21. Bhaduri, S.; Debnath, N.; Mitra, S.; Liu, Y.; Kumar, A. Microbiologically induced calcite precipitation mediated by sporosarcina pasteurii. J. Vis. Exp. 2016, 2016, e53253. [CrossRef]

22. Achal, V.; Mukherjee, A.; Basu, P.C.; Sudhakara Reddy, M. Strain improvement of Sporosarcina pasteurii for enhanced urease and calcite production. J. Ind. Microbiol. Biotechnol. 2009, 36, 981-988. [CrossRef] [PubMed]

23. Sarayu, K.; Iyer, N.R.; Murthy, A.R. Exploration on the biotechnological aspect of the ureolytic bacteria for the production of the cementitious materials-A review. Appl. Biochem. Biotechnol. 2014, 172, 2308-2323. [CrossRef] [PubMed]

24. Meier, A.; Kastner, A.; Harries, D.; Wierzbicka-Wieczorek, M.; Majzlan, J.; Büchel, G.; Kothe, E. Calcium carbonates: Induced biomineralization with controlled macromorphology. Biogeosciences 2017, 14, 4867-4878. [CrossRef]

25. Stocks-Fischer, S.; Galinat, J.K.; Bang, S.S. Microbiological precipitation of $\mathrm{CaCO}_{3}$. Soil Biol. Biochem. 1999, $31,1563-1571$. [CrossRef]

26. Grabiec, A.M.; Starzyk, J.; Stefaniak, K.; Wierzbicki, J.; Zawal, D. On possibility of improvement of compacted silty soils using biodeposition method. Constr. Build. Mater. 2017, 138, 134-140. [CrossRef]

27. Khodadadi, H.; Bilsel, H. Application of microorganisms for improvement of liquefiable sand. In Proceedings of the 3rd international conference on new developments in soil mechanics and geotechnical engineering, Near East University, Nicosia, North Cyprus, 28-30 June 2012; pp. 857-863.

28. Peng, Y.; Ding, X.-M.; Xiao, Y.; Chu, J.; Deng, W.-T. Study of particle breakage behaviour of calcareous sand by dyeing tracking and particle image segmentation method. Rock Soil Mech. 2019, 40, 2663-2672. [CrossRef] 
29. Keykha, H.; Asadi, A.; Zareian, M. Environmental Factors Affecting the Compressive Strength of Microbiologically Induced Calcite Precipitation-Treated Soil. Geomicrobiol. J. 2017, 34, 889-894. [CrossRef]

30. Umar, M.; Kassim, K.A.; Ping Chiet, K.T.; Chiet, K.T.P.; Ping Chiet, K.T.; Chiet, K.T.P. Biological process of soil im-provement in civil engineering: A review. J. Rock Mech. Geotech. Eng. 2016, 8, 767-774. [CrossRef]

31. Kaur, G.; Dhami, N.K.; Goyal, S.; Mukherjee, A.; Reddy, M.S. Utilization of carbon dioxide as an alternative to urea in biocementation. Constr. Build. Mater. 2016, 123, 527-533. [CrossRef]

32. Valencia González, Y.; Carvalho-Camapum, J.; Lara-Valencia, L.A. Influence of biomineralization on a profile of a tropical soil affected by erosive processes. DYNA 2015, 82, 221-229. [CrossRef]

33. Jamshidi-Zanjani, A.; Khodadadi, A.; Sheta, K.W. Review of Enhancement Techniques on Medical Images. Int. J. Adv. Comput. Electron. Technol. 2017, 4, 26-30. [CrossRef]

34. Virkutyte, J.; Sillanpää, M.; Latostenmaa, P. Electrokinetic soil remediation-Critical overview. Sci. Total Environ. 2002, 289, 97-121. [CrossRef]

35. Cameselle, C. Enhancement of Electro-Osmotic Flow during the Electrokinetic Treatment of a Contaminated Soil. Electrochim. Acta 2015, 181, 31-38. [CrossRef]

36. Saad, A.H.; Nahazanan, H.; Yusoff, Z.M.; Huat, B.K.; Mustafa, M. Properties of Biomineralization Process in Various Types of Soil and Their Limitations. Int. J. Eng. Adv. Technol. 2019, 9, 4261-4268.

37. Micic, S.; Shang, J.Q.; Lo, K.Y.; Lee, Y.N.; Lee, S.W. Electrokinetic strengthening of a marine sediment using intermittent current. Can. Geotech. J. 2001, 38, 287-302. [CrossRef]

38. Moghadam, M.J.; Moayedi, H.; Sadeghi, M.M.; Hajiannia, A. A review of combinations of electrokinetic applications. Environ. Geochem. Health 2016, 38, 1217-1227. [CrossRef]

39. Keykha, H.; Huat, B.B.K.K.; Asadi, A. Electrokinetic Stabilization of Soft Soil Using Carbonate-Producing Bacteria. Geotech. Geol. Eng. 2014, 32, 739-747. [CrossRef]

40. Švajlenka, J.; Kozlovská, M. Perception of User Criteria in the Context of Sustainability of Modern Methods of Construction Based on Wood. Sustainability 2018, 10, 116. [CrossRef]

41. Švajlenka, J.; Kozlovská, M.; Pošiváková, T. Analysis of Selected Building Constructions Used in Industrial Construction in Terms of Sustainability Benefits. Sustainability 2018, 10, 4394. [CrossRef]

42. British Standards Institution. General Requirements and Sample Preparation (BS1377-1); British Standards Institution: London, UK, 1990.

43. British Standards Institution. Classification Tests (BS1377-2); British Standards Institution: London, UK, 1990.

44. Kulhawy, F.H.; Mayne, P.W. Manual on Estimating Soil Properties for Foundation Design: EL-6800; Electric Power Research Institute: Washington, DC, USA, 1990; p. 299.

45. British Standards Institution. BS:1377-7 Shear Strength Tests (Total Stress); Part 7; British Standards Institution: London, UK, 1990; pp. 1-52.

46. Achal, V.; Pan, X. Influence of Calcium Sources on Microbially Induced Calcium Carbonate Precipitation by Bacillus sp. CR2. Appl. Biochem. Biotechnol. 2014, 173, 307-317. [CrossRef] [PubMed]

47. Al-Thawadi, S.M.; Cord-Ruwisch, R. Calcium Carbonate Crystals Formation by Ureolytic Bacteria Isolated from Australian Soil and Sludge. J. Adv. Sci. Eng. Res. 2012, 2, 12-26.

48. Fujita, Y.; Taylor, J.L.; Gresham, T.L.T.T.; Delwiche, M.E.; Colwell, F.S.; Mcling, T.L.; Petzke, L.M.; Smith, R.W. Stimulation of microbial urea hydrolysis in groundwater to enhance calcite precipitation. Environ. Sci. Technol. 2008, 42, 3025-3032. [CrossRef]

49. Wang, L.; Wang, J.; Xu, Y.; Chen, P.; Yuan, J.; Qian, X. Novel surface treatment of concrete bricks using acid-resistance mineral precipitation. Constr. Build. Mater. 2018, 162, 265-271. [CrossRef]

50. Tobler, D.J.; Maclachlan, E.; Phoenix, V.R. Microbially mediated plugging of porous media and the impact of differing injection strategies. Ecol. Eng. 2012, 42, 270-278. [CrossRef]

51. Van Paassen, L.A. Biogrout: Ground Improvement by Microbially Induced Carbonate Precipitation. Ph.D. Thesis, Delft University of Technology, Delft, The Netherlands, 2009.

52. Lauchnor, E.G.; Schultz, L.N.; Bugni, S.; Mitchell, A.C.; Cunningham, A.B.; Gerlach, R. Bacterially Induced Calcium Carbonate Precipitation and Strontium Coprecipitation in a Porous Media Flow System. Environ. Sci. Technol. 2013, 47, 1557-1564. [CrossRef] [PubMed]

53. Al Qabany, A.; Soga, K. Effect of chemical treatment used in MICP on engineering properties of cemented soils. Géotechnique 2013, 63, 331-339. [CrossRef]

54. Emmanuel Oke, A.; Omoregie Aghimien, D.; Olusola Olatunji, S. Implementation of Value Management as an Economic Sustainability Tool for Building Construction in Nigeria. Int. J. Manag. Value Supply Chain 2015, 6, 55-64. [CrossRef]

55. Martens, M.L.; Carvalho, M.M. Key factors of sustainability in project management context: A survey exploring the project managers' perspective. Int. J. Proj. Manag. 2017, 35, 1084-1102. [CrossRef] 